have thus far not sought large undisclosed discounts from manufacturers. However, because Canada's system of drug coverage is a loose patchwork, as in the US, if provinces increasingly negotiate such discounts we can expect a US-style outcome. That is, any hidden discount, including "price-volume agreements," between provinces and manufacturers will place upward pressure on the retail prices borne out-ofpocket. Uninsured or underinsured Canadians would thereby be subsidizing the drug purchases made by their own governments (not to mention those of the large US purchasers).

Canadian Internet pharmacy is a controversy because it creates a transparent escape route for Americans who feel pricegouged in their own country. One effect of this is strong upward pressure on Canadian retail prices. The optimal policy response for Canadians is un- clear. Banning exportation of prescription drugs from Canadian dispensaries might take pressure off Canadian drug prices in the short term, but international trends suggest that it would not remove the longterm upward pressures. Progressively more countries are negotiating various forms of confidential price discounts, placing upward pressure on global "list" prices for drugs. Canada's provincial governments could follow suit by negotiating their own discounts. To mitigate the adverse effects of inflated Canadian "retail" prices, provinces could create mechanisms to "share" savings with cash-paying consumers. Alternatively, governments could negotiate concealed discounts while expanding public pharmacare such that no Canadian bears excessive out-ofpocket drug costs, however inflated "retail" prices may be. It is increasingly likely that Cana- dians will soon face this difficult policy dilemma. We only hope that policy-makers and the public do not forget that secret price discounts also come with hidden costs.

Steven Morgan

Centre for Health Services and

Policy Research, and

Department of Health Care and

Epidemiology

University of British Columbia

Vancouver, BC

Jeremiah Hurley

Centre for Health Economics and

Policy Analysis

Department of Economics

McMaster University

Hamilton, Ont.

\section{References}

1. Danzon P, Furukawa MF. Prices and availability of pharmaceuticals: evidence from nine countries. Health Aff [Web Exclusive]; Oct 2003. Available: http://content.healthaffairs.org/cgi/co ntent/full/hlthaff.w3.521v1/DC1 (accessed 2004 Feb 23)

2. Reforming States Group. State initiatives on prescription drugs: creating a more functional market. Health Aff (Millwood) 2003;22(4):128-36.

\title{
Pharmaceutical Industry
}

\section{Internet pharmacy: the tug-of-war intensifies}

$\mathrm{A}^{1}$ larmed by the growing reimportation of prescription drugs back into the United States from Canada, American pharmaceutical manufacturers are trying to curb attempts by state and city governments to make large-scale purchases of cheaper medications. In doing so they have raised the spectre of shortages in Canada's domestic drug supply and have triggered charges that they are violating antitrust laws for the purpose of "protecting their profits."

Lured by prices that can be $70 \%$ cheaper, more than one million Americans buy their drugs from Canadian pharma-

a cies at an estimated value of more than US\$1 billion.

The US Department of Justice and several state pharmacy regulators have filed suits against some US-based stores and Web sites that process sales through Canadian pharmacies,

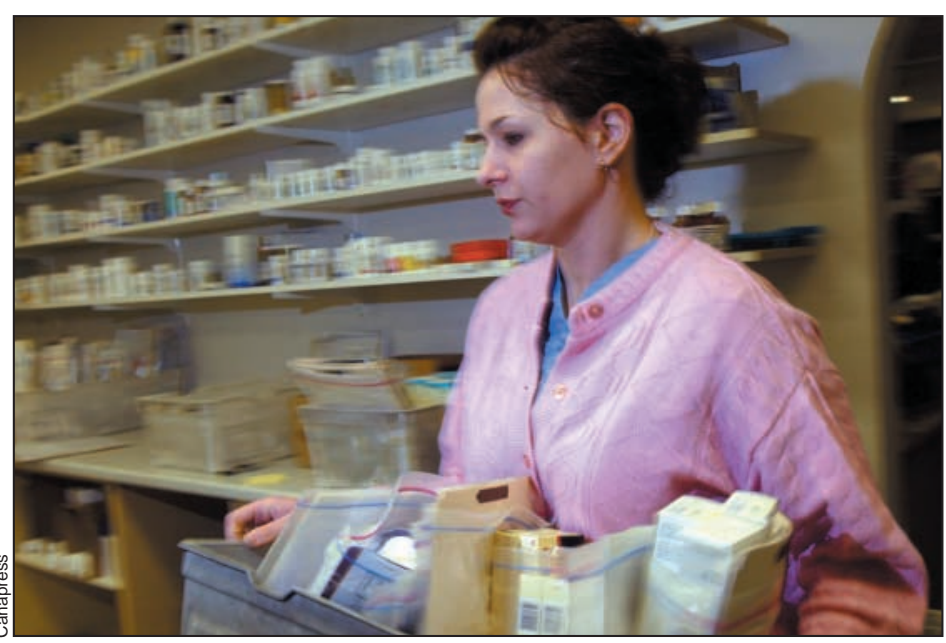

US drug manufacturers and regulators hope to curb drug reimportation through online pharmacies, such as this one based in Calgary.

but most have continued operating. There have been no suits against Canadian-based Web sites or pharmacies operating in Canada.

As the cross-border market grows, US drug manufacturers and pharmacists have become increasingly concerned about their loss of domestic sales, while US federal authorities have expressed safety concerns.

The FDA has repeatedly conducted surveillance operations to confirm the dangers of drug importation from Canada. 
None have yielded a smoking gun, although Minnesota state regulators recently cited safety violations at three of eight pharmacies inspected. These included shipping drugs requiring refrigeration in an unrefrigerated state, shipping improper amounts and failing to provide child-proof caps as required by Minnesota law. According to the Reuters news agency, that same report also praised some of the facilities, noting they "appeared to place considerable emphasis on contacting patients to discuss the proper use of their medications." (Last summer, amid concerns about the FDA's ability to oversee drug shipments within the United States, a study by the standard-setting US Pharmacopeia showed that one in four mail-order prescription deliveries within the US was likely to be exposed to excessive heat en route.)

Interviewed by Reuters, David MacKay, executive director of the Canadian International Pharmacy Association (CIPA), said most of the problems uncovered by the Minnesota investigation had been fixed and had applied only to three of the pharmacies visited.

In the wake of the Minnesota survey report, FDA Commissioner Mark McClellan again asked Health Canada for assistance in curbing the cross-border drug traffic.

Despite FDA concerns, many city and state governments want to enjoy the same kinds of savings as individuals who buy their drugs from Canada. Michael Albano, mayor of Springfield, Mass., arranged for his city's 9000 employees to buy their drugs from a designated Canadian pharmacy for an anticipated saving of between US\$4 and US\$9 million a year. The governors of West Virginia, Iowa, Ohio, Michigan, Vermont, Maine and Wisconsin are also looking for bargains. Illinois Governor Rod Blagojevich in September directed staff to explore the Canadian option. In Minnesota, Governor Tim Pawlenty did likewise and developed a Web site to enable individuals throughout the state to order drugs from Canadian pharmacies. He and Blagojevich, who projected that Illinois and its health plan participants could save almost US\$91 million by buying their drugs from Canada, have convened a national governors' summit on prescription drug reimportation for late February.

But when Blagojevich asked the FDA for permission to set up a pilot drug reimportation program to test the safety issue - an option allowed under the newly passed Medicare reform act - the FDA flatly refused, saying it could not guarantee the safety of the drugs to be used in the pilot.

Wisconsin Governor Jim Doyle asked for a similar waiver and accused major pharmaceutical companies of "a concerted and coordinated effort to impose severe restrictions on how and to whom the wholesale drugs they provide to Canadian distributors may be sold." In a news release he also castigated drug companies for being "willing to choke off the drug supply to an entire coun- try [Canada] to force American citizens to keep paying exorbitant prices."

David MacKay of the CIPA told prospective customers in the US that so long as American manufacturers embargo supplies, CIPA's 27 members have agreed not to enter into any large-scale fulfillment contracts. He wrote that five companies (Pfizer, Eli Lilly, GlaxoSmithKline, Wyeth and Astra Zeneca) have limited their shipments to Canada by either rationing product or blocking direct supply to "blacklisted" pharmacies. He added that "Pfizer has even gone so far as to threaten Canadian wholesalers with total cut off of all product permanently if they sell to these pharmacies." In substantiating that charge he produced a letter from Derek E. Sadko, Director of Sales Operations, Pfizer Canada Inc., to a distributor in western Canada, which notes that Pfizer will permit the sale of Pfizer products by distributors only to purchasers approved by Pfizer. It added that "any breach of the terms of this letter will result in Pfizer refusing all further sales of Pfizer products to you."

With US health costs hitting $15 \%$ of GDP, large employers such as governments and private industry need relief. Canada's regulated drug prices may offer some of that. But it may ultimately be up to the courts to determine whether Canada's “international" pharmacies can come to the aid of their neighbours to the South.

Milan Korcok

Fort Lauderdale, Fla. 